\title{
DEMOGRAPHICS AND CONSUMER ETHNOCENTRISM IN A Developing Country Context: A South African Study
}

\author{
Chris D Pentz, Nic S Terblanche and Christo Boshoff
}

Department of Business Management, University of Stellenbosch

Accepted: February 2014

\begin{abstract}
International trade has grown exponentially since the days of the Cold War, and today consumers in most countries are exposed to a growing range of product offerings from around the world. As the origin of products might have an influence on consumer buying behaviour, many marketers realise that an improved understanding of consumer attitudes towards both domestic and imported products could be useful in formulating more effective marketing strategies. Previous research in the field of international marketing suggests that the concept of consumer ethnocentrism can be an important factor when consumers decide to purchase locally produced rather than imported products. While the concept of consumer ethnocentrism has been actively researched in a number of contexts and countries, research on this phenomenon has been limited to developed countries. The purpose of this study is to contribute to the existing body of knowledge on consumer ethnocentrism in developing markets by investigating the possible relationships between consumer ethnocentrism and a number of demographic variables in South Africa. A unique contribution of this study is that the investigation focused on two different ethnic samples - 'white' respondents and 'black' respondents - to account for the ethnic diversity in South Africa. An online survey was used to collect data on ethnocentristic tendencies in both sub-samples, as well as on their demographic characteristics. The results of the study revealed that for both groups of respondents there was a positive relationship between age and consumer ethnocentrism, while a negative relationship was found for both groups in the relationship between consumer ethnocentrism and income. In respect of the relationship between consumer ethnocentrism and gender, the results differed between the two groups of respondents.
\end{abstract}

Key words: consumer ethnocentrism, South Africa, consumer demographics

JEL: Mзо0

\section{1}

\section{Introduction}

To remain competitive, marketers need to understand the dynamics and complexities of their target markets in an increasingly competitive and often globalised business environment. Globalisation, with its obvious consequence of increased competition, is a common threat experienced by most local firms. However, local firms can draw some comfort from an observation by Al Ganideh and Al Taee (2012) that, even though the survival of domestic firms is constantly threatened by international competitors, it seems that there are certain local consumers who view themselves as globalised, but still express a negative bias towards imported products. It can therefore be argued that local marketers, especially in developing countries, can build on these negative feelings towards imported products to encourage local consumers to purchase domestic products and, in this way, to support the domestic economy.

Previous research has revealed that one of the factors that may influence a consumer's decision to buy a domestically produced rather than a foreign-made product is the concept of consumer ethnocentrism (Altintaş \& Tokol, 2007). Luque-Martinez, Ibāńez-Zapata and Del Barrio-Garcia (2000) propose that research on consumer ethnocentrism may be a vital step towards developing a better understanding of the way in which individual and organisational consumers draw comparisons between domestic and foreign products, and of the reasons that lead to the development of patriotic prejudices against imports. It is believed that an improved understanding of whether the level of ethnocentrism influences customer attitudes towards 
products originating from overseas could be extremely useful in developing effective marketing strategies for local products (Kucukemiroglu, 1999).

It has been argued that the ethnocentric tendencies of consumers do not develop in isolation, but should rather be seen as the result of a variety of influences (Sharma, Shimp \& Shin, 1995). A number of studies (Han, 1988; Nielsen \& Spence, 1997; De Ruyter, Van Birgelen \& Wetzels, 1998, Sharma et al., 1995) have integrated the construct of ethnocentrism into models of consumer decision-making by investigating the potential antecedents or causes of ethnocentrism and by identifying moderating factors that may reduce the effect of ethnocentrism on consumers' purchase intentions (Javalgi, Khare, Gross \& Scherer, 2005). Shankarmahesh (2006) argues that four broad categories of antecedents of consumer ethnocentrism can be identified: socio-psychological; economic; political; and demographic. The focus of this study was on the fourth category, namely demographic variables - firstly because of its expected impact on ethnocentric tendencies, and secondly because the purpose of the study was to explore any potential differences in ethnocentrism between the two major ethnic groups in South Africa.

The decision to include these two different groups in the study was based on a number of reasons. The first is the fact that South Africa is inhabited by different racial groups; and authors such as Al Ganideh and Al Taee (2012) have argued that more emphasis should be placed on different subgroups in a particular country in this research field. The second is that authors such as Rossiter and Chan (1998) have argued that ethnicity is such an important phenomenon in business and consumer behaviour that it cannot be ignored as an area of scientific enquiry. The third reason for the decision was the unexplored issue of interethnic group differences in consumer ethnocentrism in multicultural nations. The empirical results reported by Klein and Ettenson (1999) and Piron (2002), for example, found that ethnicity is not a significant predictor of consumer ethnocentrism in developed countries, but also that this issue is not often formally investigated in developing countries.

As previous research (such as Shimp \&
Sharma, 1987, Vida \& Fairhurst, 1999, and Javalgi et al., 2005) suggests that demographic factors could have an impact on consumer ethnocentric tendencies, it is believed that the results of this study will fill a gap in current consumer ethnocentrism literature related to the African continent. The results of this study could thus be of value to marketers in developing more effective marketing strategies and practices.

\section{2}

\section{Consumer ethnocentrism}

The concept of consumer ethnocentrism arose from the more general concept of ethnocentrism conceived by Sumner (1906), who introduced the term as 'feelings of superiority for one's group and all things related to it' (Bawa, 2004). Consumer ethnocentrism thus refers to the tendency of consumers to exhibit a positive or favourable predisposition towards products originating from their own country, while avoiding products imported from other countries. The consequences of consumer ethnocentrism include factors such as an overestimation of the quality and value of domestic products (or an underestimation of the benefits of imports), a moral obligation to buy domestic products, and a strong preference for domestically produced products (Kaynak \& Kara, 2001).

According to Netemeyer, Durvasula and Lichtenstein (1991), one outcome of globalisation has been increased competition between domestic and multinational firms in both foreign and domestic markets. With the greater availability of foreign brands, consumers in many countries face an ever-increasing variety of buying options. It is therefore important for marketers to understand the attitudes of consumers, especially how they choose between domestic products and products of foreign origin. Kucukemiroglu (1999) argues that, combined with increased nationalism and an emphasis on cultural and ethnic identity, the concept of consumer ethnocentrism must be regarded as a potent force in the global business environment in future. It is therefore understandable that researchers such as LuqueMartinez et al. (2000) argue that research on the consumer ethnocentrism construct may be 
a vital step towards a better comprehension of how individual and organisational consumers compare domestic and foreign products, as well as the reasons why patriotic prejudices are developed about foreign products.

In the 1980s, Shimp and Sharma (1987) argued that, although scales to measure ethnocentrism did exist, they had little relevance to the study of consumer behaviour and marketing phenomena. An instrument called the Consumer Ethnocentrism Scale (CETSCALE) was subsequently developed by Shimp and Sharma to measure the ethnocentric tendencies of consumers towards buying foreign products rather than products manufactured in the United States (Shimp \& Sharma, 1987).

Against the background of Al Ganideh and Al Taee's (2012) call for more research on the impact of membership of different subgroups on ethnocentrism and the general importance of this phenomenon (Rossiter \& Chan, 1998), the CETSCALE was used to measure ethnocentrism to explore the impact of demographic antecedents on consumer ethnocentrism.

\section{3}

\section{Demographic antecedents}

To assist marketers in identifying consumers who may be sensitive toward imported merchandise, several studies have investigated the relationship between consumer ethnocentrism and various demographic variables (Huddleston, Good \& Stoel, 2001). Javalgi et al. (2005) point out that the most commonly used demographic variables in previous ethnocentrism studies are age, gender, education and income (see Table 1), and these are the focus of this study as well.

\subsection{Age}

Although earlier studies did not find a consistent relationship between age and consumer ethnocentrism, there seems to be a trend of more empirical support for the idea that older people show stronger consumer ethnocentric tendencies than younger people (Sharma et al., 1995). Table 1 lists a number of international studies whose results have shown that age was positively related to consumer ethnocentric tendencies (i.e. older people display stronger consumer ethnocentric tendencies than younger people).

However, it should be mentioned that results from some other studies (Sharma et al., 1995; Good \& Huddleston, 1995 (Russian sample), Bawa, 2004 \& Al Ganideh \& Al Taee, 2012) did not reveal a statistically significant relationship between a consumer's age and consumer ethnocentrism.

Table 1

The relationship between age and consumer ethnocentrism

\begin{tabular}{|c|c|c|c|}
\hline Author(s) & Date & Country & Type of product \\
\hline Han & 1988 & US & Television sets and automobiles \\
\hline Good and Huddleston & 1995 & Poland & Men's shirts, women's sweaters \\
\hline Caruana and Magri & 1996 & Malta & No product \\
\hline Nielsen and Spence & 1997 & US & American automobiles \\
\hline De Ruyter et al. & 1998 & $\begin{array}{l}\text { The } \\
\text { Netherlands }\end{array}$ & $\begin{array}{l}\text { Services included: public transport by bus, banking, } \\
\text { telecommunications }\end{array}$ \\
\hline Witkowski & 1998 & $\begin{array}{l}\text { Hungary; } \\
\text { Mexico }\end{array}$ & $\begin{array}{l}\text { Multiple products including: automobiles, television sets, } \\
\text { refrigerators }\end{array}$ \\
\hline Klein and Ettenson & 1999 & US & Not reported/no product \\
\hline Vida and Fairhurst & 1999 & $\begin{array}{l}\text { Czech Republic } \\
\text { Estonia; } \\
\text { Hungary; } \\
\text { Poland }\end{array}$ & Not reported/no product \\
\hline Watson and Wright & 2000 & New Zealand & Refrigerators, television sets, cameras \\
\hline Balabanis et al. & 2001 & Turkey & No product \\
\hline Orth and Firbasovā & 2003 & Czech Republic & Yoghurt \\
\hline Lee, Hong and Lee & 2003 & US & Not reported \\
\hline Javalgi et al. & 2005 & France & German cars, American computers, Japanese computers \\
\hline
\end{tabular}




\begin{tabular}{|l|l|l|l|}
\multicolumn{1}{|c|}{ Author(s) } & Date & \multicolumn{1}{c|}{ Country } & \multicolumn{1}{c|}{ Type of product } \\
\hline Verlegh & 2007 & The Netherlands & Tomatoes, apples, refrigerators, CD players \\
\hline $\begin{array}{l}\text { Chryssochoidis, Krystallis } \\
\text { and Perreas }\end{array}$ & 2007 & Greece & $\begin{array}{l}\text { Greek/Dutch beer, Greek/Italian ham products, Greek/ Dutch } \\
\text { yellow cheese }\end{array}$ \\
\hline Nguyen, Nguyen and Barrett & 2008 & Vietnam & Motorbikes, powdered milk \\
\hline $\begin{array}{l}\text { Hamelin, Ellouzi and } \\
\text { Canterbury }\end{array}$ & 2011 & Morocco & Jeans, cars, shampoo, juice \\
\hline Josiassen, Assaf and Karpen & 2011 & Australia & Not reported/no product \\
\hline Richardson & 2012 & US & Japanese products \\
\hline
\end{tabular}

As the more dominant view from previous research is that the older people are, the more ethnocentric they will be, it is proposed that:

$\mathrm{H}^{1 \mathrm{a}}$ : There is a positive relationship between age and consumer ethnocentrism among white South African consumers.

$\mathrm{H}^{1 \mathrm{~b}}$ : There is a positive relationship between age and consumer ethnocentrism among black South African consumers.

\subsection{Gender}

There seems to be a fair amount of agreement among a number of researchers that gender does influence consumer ethnocentrism, and that women generally report higher ethnocentric scores than men (see Table 2). Some of the reasons that have been given for this state of affairs are that females tend to be more conservative, patriotic, concerned with preserving social harmony and promoting positive feelings among group members, and less individualistic than males (Sharma et al., 1995).

Table 2

The relationship between gender and consumer ethnocentrism

\begin{tabular}{|l|l|l|l|}
\hline \multicolumn{1}{|c|}{ Author(s) } & Date & \multicolumn{1}{c|}{ Country } & \multicolumn{1}{c|}{ Type of product } \\
\hline Han & 1988 & US & Television sets and automobiles \\
\hline Good and Huddleston & 1995 & Poland & Men's shirts, women's sweaters \\
\hline Sharma et al. & 1995 & Korea & $\begin{array}{l}\text { Various products including: medicine, beef, bananas, } \\
\text { insurance, refrigerators }\end{array}$ \\
\hline Nielsen and Spence & 1997 & US & American automobiles \\
\hline Bruning & 1997 & Canada & Air travel \\
\hline Klein and Ettenson & 1999 & US & Not reported/no product \\
\hline Vida and Fairhurst & 1999 & Czech Republic; & Not reported/no product \\
\hline Watson and Wright & 2000 & New Zealand & Refrigerators, television sets, cameras \\
\hline Balabanis et al. & 2001 & Turkey & No product \\
\hline Lee et al. & 2003 & US & Not reported \\
\hline Javalgi et al. & 2005 & France & German cars, American computers, Japanese computers \\
\hline Josiassen et al. & 2011 & Australia & Not reported/no product \\
\hline
\end{tabular}

However, a few studies (Good \& Huddleston, 1995 (Russian sample); Caruana \& Magri, 1996; De Ruyter et al., 1998; Saffu \& Walker, 2005; Hamelin, et al., 2011; Al Ganideh \& Al Taee, 2012) did not find a significant difference between men and women in their consumer ethnocentric tendencies.

Given the weight of evidence, it is hypo- thesised that women are more ethnocentric than men:

$\mathrm{H}^{2 \mathrm{a}}$ : White South African women exhibit greater ethnocentric tendencies than white South African men.

$\mathrm{H}^{2 b}$ : Black South African women exhibit greater ethnocentric tendencies than black South African men. 


\subsection{Level of education}

Results of some prior studies seem to indicate that there is a negative relationship between consumers' education levels and consumer ethnocentrism: the more educated consumers are, the less ethnocentric they become. Some of the underlying reasons for this phenomenon are that more educated consumers tend to be less conservative, are less likely to have ethnic prejudices or be patriotic, and are more likely to favour imported over domestic products (Javalgi et al., 2005).

Table 3 lists a number of international studies whose results suggest that consumers with higher levels of education display fewer consumer ethnocentric tendencies than do consumers with lower levels of education.

Table 3

The relationship between level of education and consumer ethnocentrism

\begin{tabular}{|l|l|l|l|}
\hline \multicolumn{1}{|c|}{ Author(s) } & Date & \multicolumn{1}{c|}{ Country } & \multicolumn{1}{c|}{ Type of product } \\
\hline Good and Huddleston & 1995 & Poland & Men's shirts, women's sweaters \\
\hline Sharma et al. & 1995 & Kussia & Ken's shirts, women's sweaters \\
\hline Caruana and Magri & 1996 & Malta & $\begin{array}{l}\text { Various products including: medicine, beef, bananas, insurance, } \\
\text { refrigerators }\end{array}$ \\
\hline De Ruyter et al. & 1998 & The Netherlands & No product \\
\hline Witkowski & 1998 & Hungary: Mexico & Multiple products including: automobiles, television sets, refrigerators \\
\hline Klein and Ettenson & 1999 & US & Not reported/no product \\
\hline Watson and Wright & 2000 & New Zealand & Refrigerators, television sets, cameras \\
\hline Lee et al. & 2003 & US & Not reported \\
\hline Verlegh & 2007 & The Netherlands & Tomatoes, apples, refrigerators, CD players \\
\hline Chryssochoidis et al. & 2007 & Greece & $\begin{array}{l}\text { Greek/Dutch beer, Greek/ltalian ham products, Greek/ Dutch yellow } \\
\text { cheese }\end{array}$ \\
\hline Richardson & 2012 & US & Japanese products \\
\hline
\end{tabular}

The results of the studies reported in Table 3 are somewhat contradicted by the results reported by Han, 1988; Balabanis et al., 2001; Javalgi et al., 2005; Saffu and Walker, 2005; Nguyen, et al., 2008; and Hamelin et al., 2011, who did not find evidence that consumers' level of education is negatively related to ethnocentric tendencies.

As it seems that previous research results lean towards the notion that the more educated consumers are, the less ethnocentric they tend to be, the following hypotheses are proposed:

$\mathrm{H}^{3 \mathrm{a}}$ : There is a negative relationship between level of education and consumer ethnocentrism among white South African consumers

$\mathrm{H}^{3 \mathrm{~b}}$ : There is a negative relationship between level of education and consumer ethnocentrism among black South African consumers

\subsection{Level of income}

As in the case of education, the results of a number of previous studies (see Table 4) seem to confirm a negative relationship between consumers' income levels and consumer ethnocentrism: consumers with higher incomes appear to be less ethnocentric. Sharma et al. (1995) proposed that as their income levels increase, people tend to travel overseas more often and are then exposed to a variety of other products, which may result in alternative views and attitudes and an increased openness to products of foreign origin, unlike those who have no or limited international travel exposure. Earlier investigations of the relationship between income level and consumer ethnocentrism seem to reveal a degree of inconsistency in the results of different studies. While a number of studies have found that consumer income and ethnocentrism are negatively related (see Table 4), many studies (Han, 1988; Good \& Huddleston, 1995 (Russian sample); Caruana \& Magri, 1996; De Ruyter et al., 1998; Witkowski, 1998; Javalgi et al., 2005; Nguyen et al., 2008 and Al Ganideh \& Al Taee, 2012) did not confirm this relationship. 
Table 4

The relationship between income levels and consumer ethnocentrism

\begin{tabular}{|l|l|l|l|}
\hline \multicolumn{1}{|c|}{ Author(s) } & Date & \multicolumn{1}{c|}{ Country } & \multicolumn{1}{c|}{ Product type } \\
\hline Sharma et al. & 1995 & Korea & $\begin{array}{l}\text { Various products including: medicine, beef, bananas, } \\
\text { insurance, refrigerators }\end{array}$ \\
\hline Good and Huddleston & 1995 & Poland & Men's shirts, women's sweaters \\
\hline Bruning & 1997 & Canada & Air travel \\
\hline Klein and Ettenson & 1999 & US & Not reported/no product \\
\hline Watson and Wright & 2000 & New Zealand & Refrigerators, television sets, cameras \\
\hline Balabanis et al. & 2001 & Turkey: Czech Republic & Not reported \\
\hline Lee et al. & 2003 & US & Not reported \\
\hline Hamelin et al. & 2011 & Morocco & Jeans, cars, shampoo, juice \\
\hline Richardson & 2012 & US & Japanese products \\
\hline
\end{tabular}

Results of previous studies therefore seem to be equivocal about the relationship between income levels and consumer ethnocentrism. To explore the possible relationship between income levels and consumer ethnocentrism in a South African context, the following hypotheses are proposed:

$\mathrm{H}^{4 a}$ : There is a negative relationship between income level and consumer ethnocentrism among white South African consumers

$\mathrm{H}^{4 \mathrm{~b}}$ : There is a negative relationship between income level and consumer ethnocentrism among black South African consumers

\section{4}

\section{Objectives of the study}

The primary objective of this study was to investigate the possible effects of demographic variables on consumer ethnocentrism in a developing country, namely South Africa, and to compare the results with previous and sometimes inconsistent results. This study addresses a gap in the field of consumer ethnocentrism in developing countries (especially in the African context) by comparing the results of two different ethnic groups, and attempts to add to the existing and rather limited body of knowledge on consumer ethnocentrism in developing countries.

\section{5}

\section{Research methodology}

For the purpose of this study the population was defined as South African residents. The sample consisted of individuals of both genders who were older than 18 years and had an average gross personal income of at least R5 000 per month. The minimum income level was set to ensure that all respondents would have access to a minimum level of disposable income, and thus be able to consider buying both local and imported products. To address the primary objective of the study, two subsamples were drawn: a sample of white respondents and a sample of black respondents.

To draw the two samples, a South African provider of consumer data was provided with the required demographic specifications of the two samples (age, gender, level of income, level of education). As the collection of data was to be conducted electronically, the next step was to conduct a pilot study to assess the likely response rate of a test sample of respondents to the questionnaire used. A sample of 600 white respondents (300 male and 300 female) and a sample of 600 black respondents (300 male and 300 female) were randomly selected, and an invitation to complete the online questionnaire was sent to respondents via e-mail.

For the group 'white female' a response of 11 out of 300 (3.6 per cent) was recorded; the group 'white male' recorded a response of 9 out of 300 (3 per cent); the group 'black female' recorded a response of 5 out of 300 ( 1.7 per cent) while the group 'black male' had a response of 6 out of 300 ( 2 per cent).

Based on these results, the sample size for the formal data collection was calculated. As the minimum number of completed questionnaires required for data analysis purposes was 
500 (125 completed questionnaires per group) the number of respondents sampled was
25700 (see Table 5 for a breakdown).

Table 5

Total number of invitations per respondent group

\begin{tabular}{|l|c|}
\hline \multicolumn{1}{|c|}{ Group } & Number of respondents \\
\hline White female & 4200 \\
\hline White male & 5000 \\
\hline Total white & $\mathbf{9 2 0 0}$ \\
\hline \multicolumn{2}{|c|}{} \\
\hline Black female & 9000 \\
\hline Black male & 7500 \\
\hline Total black & $\mathbf{1 6 5 0 0}$ \\
\hline
\end{tabular}

A total of 25700 names was therefore randomly drawn (9 200 white and 16500 black) from the database to make up the two sub-samples of this study.

\subsection{Measuring instrument}

A structured questionnaire (CETSCALE developed by Shimp and Sharma (1987) Table 6(a) plus demographic questions) was developed and used as a measuring instrument for collecting primary data. This questionnaire contained structured questions, using a sevenpoint, multiple-item Likert scale with options ranging from 1 representing 'strongly disagree' to 7 representing 'strongly agree'. Ordinal and nominal scales were used to collect the demographic data of respondents, which included age, gender, level of education completed and total personal income (see Table 6(b)). The questionnaire was pre-tested by means of a pilot study to identify and eliminate possible interpretation problems (to prevent response error) and to assess the reliability of the scale.

After the pilot study had been completed, the questionnaire was edited to reflect the feedback from respondents. As a result, the wording of three questions was altered to enhance respondent understanding. For the purposes of this study an adapted version of the 10-item CETSCALE developed by Shimp and Sharma (1987) was used to measure the consumer ethnocentrism of the respondents. The adaptation pertained to the changing of the country of origin (originally being America) to South Africa. The items used in the questionnaire are listed in Table 6(a).

Table 6(a)

Adapted items used in the questionnaire to measure consumer ethnocentrism

\begin{tabular}{|l|}
\hline \multicolumn{1}{|c|}{ Item used } \\
\hline Only those products that are unavailable in South Africa should be imported \\
\hline We should purchase products manufactured in South Africa instead of letting other countries get rich off us \\
\hline South African products first, last and foremost \\
\hline South Africans should not buy foreign products, because this hurts South African business and causes unemployment \\
\hline Purchasing foreign-made products is un-South African \\
\hline It may cost me in the long run but I prefer to support South African products \\
\hline It is not right to purchase foreign products, because it puts South Africans out of jobs \\
\hline We should buy from foreign countries only those products that are unobtainable in our own country \\
\hline A real South African should always buy South African-made products \\
\hline South African consumers who purchase products made in other countries are responsible for putting their fellow South \\
Africans out of work
\end{tabular}




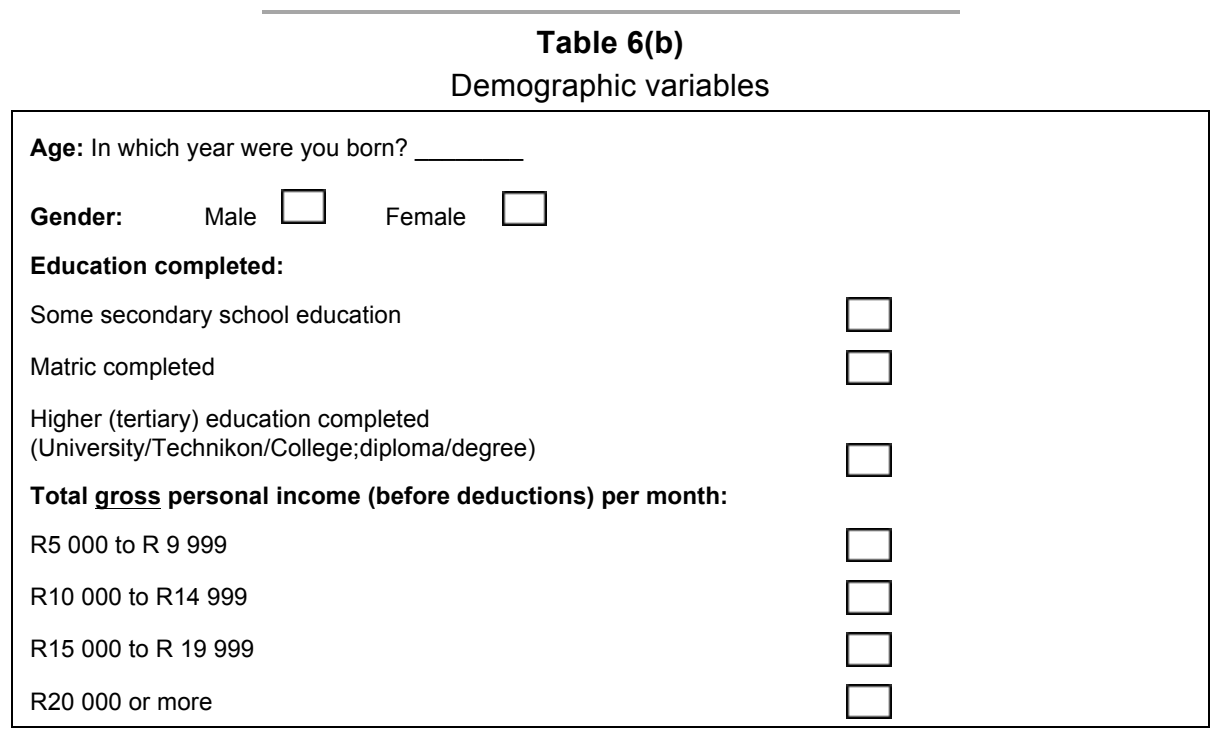

\subsection{The reliability of the CETSCALE}

The reliability and validity of the CETSCALE have been extensively tested in various countries; it was found to possess a high degree of validity and reliability (Orth \& Firbasovā, 2003). Examples of these studies include studies conducted with samples from Japan and West Germany (Netemeyer et al., 1991); Poland (Good \& Huddleston, 1995; Supphellen \& Rittenburg, 2001; Huddleston, Good \& Stoel, 2001); Malta (Caruana \& Magri, 1996); Korea (Sharma et al., 1995); Russia (Good \& Huddleston, 1995; Saffu \& Walker, 2005) and Turkey (Kavak \& Gumusluoglu, 2007). Over time, shorter versions of the CETSCALE, based on the original 17-item scale, were developed. Shimp and Sharma (1987) introduced a 10-item version of the CETSCALE, also used by authors such as Nielsen and Spence (1997); Steenkamp and Baumgartner (1998); Lindquist, Vida, Plank and Fairhurst (2001); Douglas and Nijssen (2003); Bawa (2004); and Evanschitzky, Wagenheim, Woisetschläger and Blut (2008).

\subsection{Method of data collection}

A web-based approach was used to distribute the questionnaire to the two sub-samples. An e-mail with a covering letter providing the background to the study, and an invitation to complete the online questionnaire was sent to each respondent, who was requested to click on a link connected to the website where the questionnaire was hosted.

Respondents who had not responded to the invitation to complete and submit the questionnaire one week after the first invitation had been sent received a reminder notice. In total 170 questionnaires were received from the sample of white females; 172 from the sample of white males; 200 from the sample of black females; and 217 from the sample of black males. A total of 759 completed questionnaires was received and subsequently analysed.

\subsection{Analysis of data}

To assess the reliability of the CETSCALE, Cronbach's Alpha was used. When exploring the differences between demographic variables that were nominally scaled and ethnocentrism scores, independent-sample t-tests were conducted. When both independent and dependent variables were interval-scaled, simple multiple regressions were conducted.

\section{6}

\section{Empirical results}

\subsection{Influence of demographic variables on consumer ethnocentrism for the sample of white respondents}

To assess whether the ordinally scaled demographic variables (independent variables) had an influence on consumer ethnocentrism, a 
multiple regression analysis was conducted. The demographic variables included were age, income and education. The results are reported in Table 7.

Table 7

The influence of demographic variables on consumer ethnocentrism: white sub-sample

\begin{tabular}{|c|c|c|c|c|}
\hline \multicolumn{4}{|c|}{ Dependent variable: Consumer ethnocentrism } & \multirow{3}{*}{ Tolerance/VIF } \\
\hline \multicolumn{4}{|l|}{ R-square $=0.072$} & \\
\hline Independent variables & Beta-value & t-value & p-value & \\
\hline Age & 0.148 & 2.742 & $0.006^{* * *}$ & $0.939 / 1.065$ \\
\hline Education & -0.007 & -0.118 & 0.906 n.s. & $0.832 / 1.202$ \\
\hline Income & -0.258 & -4.375 & $0.000^{* * *}$ & $0.787 / 1.271$ \\
\hline
\end{tabular}

Significance level:

*** $\quad p<0.001$

n.s. not significant

In terms of the demographic variable age, the hypothesis $\left(\mathrm{H}^{1 \mathrm{a}}\right)$ that there is a positive relationship between age and consumer ethnocentrism for white South African consumers is supported (Beta-value 0.148; t-value 2.742; p $<0.01)$. This result suggests that the older white South African consumers are, the more ethnocentric they are. This finding is consistent with findings of previous studies (Caruana and Magri, 1996; Nielsen and Spence, 1997; De Ruyter et al., 1998; Vida and Fairhurst, 1999; Lee et al., 2003 and Javalgi et al., 2005; Josiassen et al., 2011; Richardson, 2012).

As far as education is concerned, the hypothesis $\left(\mathrm{H}^{3 \mathrm{a}}\right)$ that there is a negative relationship between level of education and consumer ethnocentrism for white South African consumers is rejected (Beta-value 0.007 ; t-value of $-0.118 ; \mathrm{p}>0.05$ ). It therefore seems that the level of education of white South Africans does not have an influence on their level of ethnocentrism. This finding contradicts the findings often reported in the literature (see Table 3) in respect of the white demographic group.

For the demographic variable income, the hypothesis $\left(\mathrm{H}^{4 \mathrm{a}}\right)$ that there is a negative relationship between income and consumer ethnocentrism for white South African consumers cannot be rejected (Beta value 0.258 ; t-value $-4.375 ; \mathrm{p}<0.001)$. This result confirms that the higher the income of white South African consumers, the less ethnocentric they are. This finding concurs with findings of previous studies (Sharma et al., 1995; Klein and Ettenson, 1999 and Lee et al., 2003;
Hamelin et al., 2011; Richardson, 2012) where a negative relationship between consumer income level and consumer ethnocentric tendencies was reported. The relatively high Beta value also indicates that this variable is one of the strongest predictors of ethnocentrism in this study.

It should be noted that the $\mathrm{R}^{2}$ value of 0.072 suggests that only 7.2 per cent of variance in the score of consumer ethnocentrism is explained by the three independent demographic variables of age, income and education for the sample of white respondents.

To investigate whether white South African women exhibit greater ethnocentric tendencies than white South African men, an independent sample t-test was conducted. An independent sample t-test is used to assess the statistical significance of the difference between two sample means (see Table 8).

The results of the test of differences between means (Table 8 ) indicate that there is indeed a statistical difference $(p<0.01)$ between ethnocentric tendencies of white South African women (means score 4.7400) and men (4.1744). In other words, white South African women do seem to exhibit greater ethnocentric tendencies than white South African men. Hypothesis $\mathrm{H}_{2 \mathrm{a}}$ can thus not be rejected. This finding is consistent with findings of previous studies where gender was investigated (Sharma et al., 1995; Nielsen \& Spence, 1997; Vida \& Fairhurst, 1999; Lee et al., 2003 and Javalgi et al., 2005; Josiassen et al., 2011). 
Table 8

Influence of gender on consumer ethnocentrism: white sub-sample

\begin{tabular}{|l|c|c|}
\hline \multicolumn{3}{|c|}{ Group statistics } \\
\hline Gender & n & Mean \\
\hline Male & 172 & 4.1744 \\
\hline Female & 170 & 4.7400 \\
\hline
\end{tabular}

\begin{tabular}{|c|c|c|c|}
\hline \multicolumn{3}{|c|}{ Independent samples t-test } & \multirow{3}{*}{ p-value } \\
\hline & \multicolumn{2}{|c|}{ t-test for equality of means } & \\
\hline & $\mathbf{t}$ & df & \\
\hline Equal variances assumed* & -3.335 & 340 & $P<0.01$ \\
\hline
\end{tabular}

6.2 Influence of demographic data on consumer ethnocentrism for the sample of black respondents

As with the sample of white respondents, a multiple regression analysis was conducted to assess whether the ordinally-scaled demo- graphic variables (independent variables) exerted an influence on the dependent variable, consumer ethnocentrism. The demographic variables also included age, income and education. The results are reported in Table 9.

Table 9

The influence of demographic variables on consumer ethnocentrism: black sub-sample

\begin{tabular}{|c|c|c|c|c|}
\hline \multicolumn{4}{|c|}{ Dependent variable: Consumer ethnocentrism } & \multirow{3}{*}{ Tolerance/VIF } \\
\hline \multicolumn{4}{|l|}{ R-square $=0.047$} & \\
\hline Independent variables & Beta-value & t-value & $p$-value & \\
\hline Age & 0.142 & 2.863 & $0.004^{* * *}$ & $0.945 / 1.059$ \\
\hline Education & -0.086 & -1.652 & 0.099 n.s. & $0.852 / 1.173$ \\
\hline Income & -0.128 & -2.427 & $0.016^{*}$ & $0.825 / 1.212$ \\
\hline
\end{tabular}

Significance level:

${ }^{*} p<0.05$

${ }^{* * *} p<0.001$

n.s. not significant

As far as age is concerned, the hypothesis $\left(\mathrm{H}^{1 \mathrm{~b}}\right)$ that there is a positive relationship between age and consumer ethnocentrism for black South African consumers is supported (Beta value 0.142; t-value 2.863; $\mathrm{p}<0.01$ ). This result suggests that the older black South African consumers are, the more ethnocentric they are, and corresponds with the findings of previous studies (Caruana \& Magri, 1996; Nielsen \& Spence, 1997; De Ruyter et al., 1998; Vida \& Fairhurst, 1999; Lee et al., 2003; Javalgi et al., 2005; Josiassen et al., 2011; Richardson, 2012).

In terms of education, the hypothesis $\left(\mathrm{H}^{3 \mathrm{~b}}\right)$ that there is a negative relationship between level of education and consumer ethnocentrism for black South African consumers is rejected ( $\mathrm{t}$-value $-1.652 ; \mathrm{p}>0.05$ ). This result suggests that the level of education of black South Africans does not influence their level of ethnocentrism. This finding is similar to that of the white sample where the findings contradict earlier reported findings (see Table 3 ).

Hypothesis $\mathrm{H}_{4 \mathrm{~b}}$, related to the variable income, i.e. that there is a negative relationship between income and consumer ethnocentrism for black South African consumers, is supported (t-value $-2.427 ; \mathrm{p}<0.05$ ). This result suggests that the higher the income of black South African consumers, the less ethnocentric they are, and concurs with the findings of previous studies (Sharma et al., 1995; Klein \& 
Ettenson, 1999; Lee et al., 2003; Hamelin et al., 2011; Richardson, 2012).

As with the sample of white respondents, it should be noted that the $\mathrm{R}^{2}$ value of 0.047 suggests that only 4.7 per cent of variance in the score of consumer ethnocentrism is explained by the three independent demo- graphic variables of age, income and education for the sample of black respondents.

To investigate whether black South African women exhibit greater ethnocentric tendencies than black South African men, an independent sample t-test was also conducted (see Table 10).

Table 10

Influence of gender on consumer ethnocentrism: black sub sample

\begin{tabular}{|l|l|l|}
\hline \multicolumn{3}{|c|}{ Group statistics } \\
\hline Gender & $\mathrm{n}$ & Mean \\
\hline Male & 217 & 4.6306 \\
\hline Female & 200 & 4.5992 \\
\hline
\end{tabular}

\begin{tabular}{|l|c|c|c|}
\hline \multicolumn{4}{|c|}{ Independent samples t-test } \\
\hline \\
\cline { 2 - 4 } & t-test for equality of means & p-value \\
\hline Equal variances assumed* & $\mathbf{0 . 2 1 5}$ & df & $\mathbf{0 . 8 3 0}$ \\
\hline
\end{tabular}

* Levene's test of for equality of means: $F=3.407 ; p>0.066$

The results of the test of differences (Table 10) indicate that there does not seem to be a difference between the ethnocentric tendencies of black South African women (mean score 4.5992) and men (mean score 4.6306) and $p=$ 0.830 . Hypothesis $\mathrm{H}_{2 \mathrm{~b}}$ can therefore be rejected, as black males and females hold very similar views on consumer ethnocentrism.

\section{7}

\section{Summary of empirical findings}

From the empirical results (summarised in Table 11) it is clear that there is a difference between the samples of white and black respondents in terms of the relevance of the demographic antecedents in shaping consumer ethnocentrism. In both groups, age and income exert an influence on consumer ethnocentrism. Results from the sample of white respondents, however, also revealed that gender has an influence on the level of consumer ethnocentrism, while gender was not significant for the sample of black respondents. The conclusion, therefore, is that even though there was significant congruence between the samples of white and black respondents for this study, there were also some differences.

\subsection{Conclusions and marketing implications}

The primary objective of this study was to investigate the possible effects of demographic variables on consumer ethnocentrism in a developing country, South Africa. The results of this investigation suggest that, as far as demographic antecedents (age, gender, level of education and level of income) are concerned, marketing managers wishing to focus on consumer ethnocentrism should pay specific attention to the variables of age and income. In terms of marketing strategies, the results also suggest that more-or-less similar strategies could be used by marketing managers for white and black South African consumers when dealing with consumer ethnocentrism. These strategies should still be differentiated in line with, for example, the difference in terms of gender that was found between the two sub samples of the study. This finding is consistent with the views of Vida, Dmitrović \& Obadia (2008), whose results indicated that a differentiated or 'multi-local' marketing strategy may be justified in countries where there are multi-ethnic markets. 
Table 11

Summary of empirical results

\begin{tabular}{|l|l|c|}
\hline $\mathrm{H}^{1 \mathrm{a}}:$ & $\begin{array}{l}\text { There is a positive relationship between age and consumer ethnocentrism among } \\
\text { white South African consumers }\end{array}$ & Supported \\
\hline $\mathrm{H}^{1 \mathrm{~b}}:$ & $\begin{array}{l}\text { There is a positive relationship between age and consumer ethnocentrism among } \\
\text { black South African consumers }\end{array}$ & Supported \\
\hline $\mathrm{H}^{2 \mathrm{a}}:$ & $\begin{array}{l}\text { White South African women exhibit greater ethnocentric tendencies than white } \\
\text { South African men }\end{array}$ & Supported supported \\
\hline $\mathrm{H}^{2 \mathrm{~b}}:$ & $\begin{array}{l}\text { Black South African women exhibit greater ethnocentric tendencies than black } \\
\text { South African men }\end{array}$ & Not supported \\
\hline $\mathrm{H}^{3 \mathrm{a}}:$ & $\begin{array}{l}\text { There is a negative relationship between level of education and consumer } \\
\text { ethnocentrism among white South African consumers }\end{array}$ & Not supported \\
\hline $\mathrm{H}^{3 \mathrm{~b}}:$ & $\begin{array}{l}\text { There is a negative relationship between level of education and consumer } \\
\text { ethnocentrism among black South African consumers }\end{array}$ & $\begin{array}{l}\text { Supported } \\
\text { among white South African consumers }\end{array}$ \\
\hline $\mathrm{H}^{4 \mathrm{a}}:$ & $\begin{array}{l}\text { There is a negative relationship between income level and consumer ethnocentrism } \\
\text { among black South African consumers }\end{array}$ & Supported \\
\hline $\mathrm{H}^{4 b}:$ & \begin{tabular}{l} 
There is negative relationship between income level and consumer ethnocentrism \\
\hline
\end{tabular}
\end{tabular}

The results suggest that younger consumers seem to be less ethnocentric, while consumers with higher incomes also seem to be less ethnocentric than consumers with lower incomes. Depending on the product, marketing managers could incorporate this insight into their marketing strategies. With older consumers, who tend to be more ethnocentric, strategies could be developed to focus on them. Promotional messages containing patriotic themes could be used to communicate with these consumers. Taking into account the media usage patterns of older consumers, these messages can appear in relevant magazines, on television during selected programmes and news bulletins, and on radio stations. Local firms could, for example, also communicate to older consumers how many jobs they provide in their country, as well as their level of investment in the country. Consumers could then be urged either to continue buying local products or to start buying local products to 'support their country'. To enhance this message, domestic firms could engage in cause-related marketing by communicating that they would donate funds to worthwhile causes within the country (such as AIDS orphanages) for every locally produced product bought. To make the strategy more relevant (closer to home), the country could be divided into regions, with a suitable beneficiary (cause) identified for each region. The messages promoting a particular beneficiary would then be placed in the most influential media of the specific area.

Local firms could also use brands for their products that typically relate to their country. South African brands such as 'Namaqua', 'Ceres', 'Willeklong', 'Out of the blue (Knysna)'. Amarula already emphasise the fact that the product is South African, and not imported. A local firm can furthermore consider becoming a member of the Proudly South African (or buy local) campaign. One of the objectives of the Proudly South African campaign is to encourage South Africans to buy local products, to stimulate the local economy and support job creation. By adding the Proudly South African logo to their products a firm specifies that the product is of good quality; that employees are treated fairly; that the company cares for the environment; and that the total product is manufactured in South Africa or at least 50 per cent of the cost of production was incurred locally. In this way national pride, patriotism and social cohesion are encouraged. If more South African firms could therefore associate with the 'Proudly South African' campaign, it is likely to promote more South African products and services.

Raising the level of ethnocentrism among younger consumers, who tend to be less ethnocentric, could pose some difficulties. Marketing managers could therefore develop strategies other than those targeted at promoting consumer ethnocentrism to persuade these younger consumers to buy local products. A possible exception is that a strategy could be 
used to inform younger people that buying local products would not only protect existing jobs, but could even create new job opportunities for them. This information could be disseminated at schools, universities, technikons and technical colleges in the form of posters on notice boards, by means of roadshows/industrial theatre, or by empowering teachers and/or academics to convey the message to students/learners. The message could also be communicated in a way that younger people can relate to (i.e. not 'oldfashioned'). Messages can be aired in timeslots during programmes watched by younger people on local television channels. Wellknown local sports stars and other celebrities could, for example, be used to convey these messages. Firms selling/manufacturing local products can also post messages promoting this fact on their Facebook and Twitter sites. Firms can further promote the fact that they sell local products by 'telling stories' on their company blogs - for example, telling how many local people they employ, and how many individuals are supported through the salaries/ wages their employees earn. Messages promoting local produce can also be posted on other blogs, such as that of Brand South Africa.

As far as gender is concerned, the results of the study indicate that this antecedent is only relevant for consumer ethnocentrism in the sample of white South African respondents. This finding implies, therefore, that South African marketing managers could focus the strategies proposed above, and others, on (white) South African women where appropriate, as they may well be more receptive than South African men. Media such as predominantly women's magazines, and television and radio programmes focusing on female issues, could be used to carry advertisements with patriotic themes. More retailers that sell clothing (such as Cape Union Mart, Woolworths and $\mathrm{Mr}$ Price) could also accentuate the fact that certain clothing items sold by them are produced in South Africa.

It is believed that the findings of this study contribute to the body of knowledge on consumer ethnocentrism literature in developping countries by comparing the attitudes of two ethnic groups in the same country. It is hoped that the results and suggestions can be used effectively by marketers in developing countries in the formulation of more actionable and effective marketing strategies and practices.

\section{8}

\section{Limitations of the study}

As it was important to survey only respondents who have access to enough disposable income to be able to choose between imported and locally-produced products, lower level income earners were excluded from this study. In addition, only the two major ethnic groups in South Africa were surveyed and compared. As it is possible that lower income level consumers and those from other ethnic groups may hold different views on ethnocentrism, the limitations of our study leave scope for future research.

\section{References}

AL GANIDEH, S.F. \& AL TAEE, H. 2012. Examining consumer ethnocentrism amongst Jordanians from an ethnic group perspective. International Journal of Marketing Studies, 4(1):48-57.

ALTINTAŞ, M.H. \& TOKOL, T. 2007. Cultural openness and consumer ethnocentrism: An empirical analysis of Turkish consumers. Marketing Intelligence \& Planning, 25(4):308-325.

BALABANIS, G., DIAMANTOPOULOS, A., MUELLER, R.D. \& MELEWAR, T.C. 2001. The impact of nationalism, patriotism and internationalism on consumer ethnocentric tendencies. Journal of International Business Studies, 32(1):157-175.

BAWA, A. 2004. Consumer ethnocentrism: CETSCALE validation and measurement of extent. Vikalpa, 29(3):43-57.

BRUNING, E.R. 1997. Country of origin, national loyalty and product choice: The case of international air travel. International Marketing Review, 14(1):59-74.

CARUANA, A. \& MAGRI, E. 1996. The effects of dogmatism and social class variables on consumer ethnocentrism in Malta. Marketing Intelligence and Planning, 14(4):39-44. 
CHRYSSOCHOIDIS, G., KRYSTALLIS, A. \& PERREAS, P. 2007. Ethnocentric beliefs and country-oforigin (COO) effect: Impact of country, product and product attributes on Greek consumers' evaluation of food products. European Journal of Marketing, 41(11/12):1518-1544.

DE RUYTER, K., VAN BIRGELEN, M. \& WETZELS, M. 1998. Consumer ethnocentrism in international services marketing. International Business Review, 7:185-202.

DOUGLAS, S.P. \& NIJSSEN, E.J. 2003. On the use of 'borrowed' scales in cross-national research. International Marketing Review, 20(6):621-642.

EVANSCHITZKY, H., WANGENHEIM, F., WOISETSCHLÄGER, D. \& BLUT, M. 2008. Consumer ethnocentrism in the German market. International Marketing Review, 25(1):7-32.

GOOD, L.K. \& HUDDLESTON, P. 1995. Ethnocentrism of Polish and Russian consumers: are feelings and intentions related? International Marketing Review, 12(5):35-48.

HAMELIN, N., ELLOUZI, M. \& CANTERBURY, A. 2011. Consumer ethnocentrism and country-of-origin effects in the Moroccan market. Journal of Global Marketing, 24(3):228-244.

HAN, C.M. 1988. The role of consumer patriotism in the choice of domestic versus foreign products. Journal of Advertising Research, June/July:25-32.

HUDDLESTON, P., GOOD, L.K. \& STOEL, L. 2001. Consumer ethnocentrism, product necessity and Polish consumers' perceptions of quality. International Journal of Retail \& Distribution Management, 29(5):236-246.

JAVALGI, R.G., KHARE, V.P., GROSS, A.C. \& SCHERER, R.F. 2005. An application of the consumer ethnocentrism model to French consumers. International Business Review, 14(3):325-344.

JOSIASSEN, A., ASSAF, A.G. \& KARPEN, I.O. 2011. Consumer ethnocentrism and willingness to buy: analyzing the role of three demographic consumer characteristics. International Marketing Review, 28(6):627-646.

KAVAK, B. \& GUMUSLUOGLU, L. 2007. Segmenting food markets: the role of ethnocentrism and lifestyle in understanding purchasing intentions. International Journal of Market Research, 49(1):71-94.

KAYNAK, E. \& KARA, A. 2001. An examination of the relationship among consumer lifestyles, ethnocentrism, knowledge structures, attitudes and behavioral tendencies: a comparative study in two CIS states. International Journal of Advertising, 20(4):455-482.

KLEIN, J.G. \& ETTENSON, R. 1999. Consumer animosity and consumer ethnocentrism: An analysis of unique antecedents. Journal of International Consumer Marketing, 11(4):5-24.

KUCUKEMIROGLU, O. 1999. Market segmentation by using consumer lifestyle dimensions and ethnocentrism. European Journal of Marketing, 33(5/6):470-487.

LEE, W., HONG, J. \& LEE, S. 2003. Communicating with American consumers in the post 9/11 climate: An empirical investigation of consumer ethnocentrism in the United States. International Journal of Advertising, 22(4):487-510.

LINDQUIST, J.D., VIDA, I., PLANK, R.E. \& FAIRHURST, A. 2001. The modified CETSCALE: Validity tests in the Czech Republic, Hungary and Poland. International Business Review, 10(5):505-516.

LUQUE-MARTINEZ, T., IBAĀŃEZ-ZAPATA, J. \& DEL BARRIO-GARCIA, S. 2000. Consumer ethnocentrism measurement: an assessment of the reliability of the CETSCALE in Spain. European Journal of Marketing, 34(11/12):1353-1373.

NETEMEYER, R.G., DURVASULA, S. \& LICHTENSTEIN, D.R. 1991. A cross-national assessment of the reliability and validity of the CETSCALE. Journal of Marketing Research, XXVIII(August):320-327.

NGUYEN, T.D., NGUYEN, T.T.M. \& BARRETT, N.J. 2008. Consumer ethnocentrism, cultural sensitivity, and intention to purchase local products: evidence from Vietnam. Journal of Consumer Behaviour, 7(1):88100.

NIELSEN, J.A. \& SPENCE, M.T. 1997. A test of the stability of the CETSCALE, a measure of consumers' ethnocentric tendencies. Journal of Marketing Theory and Practice, 5(4):68-76.

ORTH, U.R. \& FIRBASOVĀ, Z. 2003. The role of consumer ethnocentrism in food product evaluation. Agribusiness, 19(2):137-153.

PIRON, F. 2002. International outshopping and ethnocentrism. European Journal of Marketing, 36(1/2):189210. 
RICHARDSON, C.W. (Jr.) 2012. Consumer demographics as antecedents in the animosity model of foreign product purchase. International Journal of Business and Social Science, 3(4):13-21.

ROSSITER, J.R. \& CHAN, A.M. 1998. Ethnicity in business and consumer behavior. Journal of Business Research, 42(2):127-134.

SAFFU, K. \& WALKER, J.H. 2005. An assessment of the consumer ethnocentric scale (CETSCALE) in an advanced and transitional country: The case of Canada and Russia. International Journal of Management, 22(4):556-571.

SHANKARMAHESH, M.N. 2006. Consumer ethnocentrism: An integrative review of its antecedents and consequences. International Marketing Review, 23(2):146-172.

SHARMA, S., SHIMP, T.A. \& SHIN, J. 1995. Consumer ethnocentrism: A test of antecedents and moderators. Journal of the Academy of Marketing Science, 23(1):26-37.

SHIMP, T.A. \& SHARMA, S. 1987. Consumer ethnocentrism: Construction and validation of the CETSCALE. Journal of Marketing Research, XXIV(August):280-289.

STEENKAMP, J-B.E.M. \& BAUMGARTNER, H. 1998. Assessing measurement invariance in crossnational consumer research. Journal of Consumer Research, 25(1):78-90.

SUMNER, W.G. 1906. Folkways: a study of the sociological importance of usages, manners, customs, mores, and morals. Boston: Ginn \& Company.

SUPPHELLEN, M. \& RITTENBURG, T.L. 2001. Consumer ethnocentrism when foreign products are better. Psychology \& Marketing, 18(9):907-927.

VERLEGH, P.W.J. 2007. Home country bias in product evaluation: The complementary roles of economic and socio-psychological motives. Journal of International Business Studies, 38(3):361-373.

VIDA, I., DMITROVIČ, T. \& OBADIA, C. 2008. The role of ethnic affiliation in consumer ethnocentrism. European Journal of Marketing, 42(3/4):1-13.

VIDA, I. \& FAIRHURST, A. 1999. Factors underlying the phenomenon of consumer ethnocentricity: evidence from four European countries. The International Review of Retail, Distribution and Consumer Research, 9(4):321-337.

WATSON, J.J. \& WRIGHT, K. 2000. Consumer ethnocentrism and attitudes toward domestic and foreign products. European Journal of Marketing, 34(9/10):1149-1166.

WITKOWSKI, T.H. 1998. Consumer ethnocentrism in two emerging markets: Determinants and predictive validity. Advances in Consumer Research, 25(1):258-263. 